\title{
ESTIMATION OF INBUILT AGE IN RADIOCARBON AGES OF SOIL CHARCOAL FOR FIRE HISTORY STUDIES
}

\author{
Daniel G Gavin \\ College of Forest Resources, University of Washington - Box 352100, Seattle, Washington 98195 USA. \\ Email: dgavin@u.washington.edu.
}

\begin{abstract}
Radiocarbon age determinations of wood charcoal are commonly used to date past forest fire events, even though such ages should be greater than the fire event due to the age of the wood at the time of burning. The difference in the ${ }^{14} \mathrm{C}$-derived age of charcoal and the time-since-fire (the "inbuilt age") may be considerable in some vegetation types and thus must be estimated before interpreting fire dates. Two methods were used to estimate the potential range of inbuilt age of soil charcoal dated to determine ages of forest fires on the west coast of Vancouver Island (Canada). First, $26{ }^{14} \mathrm{C}$ ages on charcoal in surficial soil were compared directly with ages of forest fire determined by tree-ring counts, suggesting inbuilt ages of 0 670 years. Second, a simulation model that uses estimated fuel loads, fuel consumption, charcoal production, and the ages of charred wood (time since wood formation), suggests that the combination of slow growth rates and slow decay rates of certain species can account for inbuilt ages of more than 400 years in this forest type. This level of inbuilt age is large enough such that the actual age of a fire may not occur within the $2 \sigma$ confidence interval of a calibrated charcoal ${ }^{14} \mathrm{C}$ age determination, and thus significantly affect the interpretation of fire dates. A method is presented to combine the error of a calibrated ${ }^{14} \mathrm{C}$ age determination with the error due to inbuilt age such that the larger adjusted error encompasses the actual age of the fire.
\end{abstract}

\section{INTRODUCTION}

Radiocarbon ages of wood charcoal from soils are commonly used to determine ages of fire events (Molloy et al. 1963; Turner 1984; Horn and Sanford 1992; Hopkins et al. 1993; Carcaillet 1998). Two sources of error must be addressed in this approach. The first, the standard error of a ${ }^{14} \mathrm{C}$ measurement and the calibration from the ${ }^{14} \mathrm{C}$ to the calendar time scale, is internal to the method and can be readily quantified using established techniques (Aitken 1990; Stuiver and Reimer 1993). The second, the age of the measured sample relative to the time-since-fire, is less well understood and more difficult to quantify. This uncertainty occurs because ${ }^{14} \mathrm{C}$ age represents the time since carbon was removed from the atmosphere and incorporated into the sample, but, in many situations, the wood was already decades to centuries old at the time of the fire. The resulting 'inbuilt age' or 'presample age' error is defined as the difference between the time since wood formation and the age of the event of interest (e.g. fire) (McFadgen 1982). Inbuilt age always biases ${ }^{14} \mathrm{C}$ ages to be older than the event (Waterbolk 1983). Because it is possible for wood to remain intact for centuries before burning, it is possible that the inbuilt age may be large enough that the $2 \sigma$ confidence interval of a calibrated ${ }^{14} \mathrm{C}$ age does not encompass the time of the fire.

McFadgen (1982), in a review of the potential effect of inbuilt age for the interpretation of ${ }^{14} \mathrm{C}$ ages from archeological sites, described inbuilt age as the sum of two components. The first occurs because charcoal may have resulted from a fire that happened at some time following the death of the plant. This component is affected by the residence time of dead wood on the ground or as dead branches in trees (i.e. time-since-death). The second occurs because the charcoal may represent wood layers located at some depth within a branch or log, rather than on the most recent growth increments. This component is affected by the number of years of wood growth that occurred subsequent to the formation of the wood that is dated. Thus the inbuilt age can be reduced by choosing species with short life spans and/or sample residence times, such as wood from short-lived species or small twigs (McFadgen 1982, 1994; Waterbolk 1983; Lowe et al. 1998). In some cases, however, the material available for ${ }^{14} \mathrm{C}$ dating does not meet these criteria. In these cases, there is an uncertain inbuilt age, and ${ }^{14} \mathrm{C}$ ages should be considered a maximum age of the fire. 
As with archeological samples, soil charcoal used to determine the dates of past fires requires the consideration of inbuilt age. Though most fire history studies using soil charcoal acknowledge the effect of inbuilt age (e.g. Molloy et al. 1963), it is often assumed to be less than the confidence interval of the ${ }^{14} \mathrm{C}$ measurement (Turner 1984; Carcaillet 1998). This assumption has never been tested. If inbuilt age is significant, the violation of this assumption will result in overestimation of time-sincefire and will limit the ability to estimate fire intervals from multiple ${ }^{14} \mathrm{C}$ ages from the same location.

The goal of this study is to estimate the magnitude of inbuilt age in ${ }^{14} \mathrm{C}$ ages of soil charcoal used to reconstruct the fire history of a watershed in western Vancouver Island, British Columbia (Canada). Two approaches were used to estimate inbuilt ages. First, inbuilt age was empirically documented using AMS (accelerator mass spectrometry) ${ }^{14} \mathrm{C}$ ages of soil charcoal and tree-ring ages of known fires. The difference between the known age of a fire and the calibrated ${ }^{14} \mathrm{C}$ age is a direct measure of inbuilt age. Combining inbuilt ages from samples at several sites provides an estimate of the inbuilt ages representative of the study area. Second, inbuilt age was simulated for representative forest types using a model parameterized by a set of forest plot measurements and reasonable estimates of fuel age and consumption by fire. In addition to estimating the range of possible inbuilt age, means of addressing the inbuilt-age error with sampling strategies or statistical methods are also discussed.

\section{RATIONALE}

A key concept for this analysis is the inbuilt-age distribution, defined here as the frequency distribution of charcoal pieces in different age classes (representing different times since wood formation) at the time of a fire. Inbuilt-age distributions indicate the magnitude of the lag between wood formation and the fire event (Figure 1). The amount of charcoal produced by the combustion of fuels with different times since formation (e.g. live branches versus dead wood) directly affects the inbuilt-age distribution. A fire that burns mainly live branches will produce more charcoal with little inbuilt age than a fire that burns mainly old decaying logs. The inbuilt-age distribution can also be thought of as a probability distribution for the inbuilt age of a randomly selected piece of charcoal. For example, the probability that a piece of charcoal has an inbuilt age between 50 and 100 years is equivalent to the proportion of all charcoal pieces in that age class. If the general form of the inbuilt-age distribution can be approximated, then ${ }^{14} \mathrm{C}$ ages of soil charcoal can be interpreted with respect to the added error from inbuilt age.

\section{STUDY AREA}

This study was conducted in the Clayoquot River Valley $\left(49^{\circ} 15^{\prime} \mathrm{N}, 125^{\circ} 35^{\prime} \mathrm{W}\right)$ located on the west coast of Vancouver Island, British Columbia, Canada, where annual precipitation is $>3500 \mathrm{~mm}$. In the biogeoclimatic ecosystem classification system of British Columbia (Meidinger and Pojar 1991), the valley is in the very wet maritime variant of the Coastal Western Hemlock zone. The valley contains undisturbed forests dominated by western redcedar (Thuja plicata) and western hemlock (Tsuga heterophylla). Sitka spruce (Picea sitchensis) and red alder (Alnus rubra) occur mainly on floodplains. Forests on better drained terraces and alluvial fans are dominated by western hemlock and Pacific silver fir (Abies amabilis). Douglas-fir (Pseudotsuga menziesii) has a very patchy distribution, and its presence usually indicates the occurrence of fire in the recent past (Schmidt 1970; Gavin 2000). In this forest type, western redcedar may exceed 1000 years in age (Daniels et al. 1995), but western hemlock and Pacific silver fir are usually less than 500 years.

Old-growth western hemlock forests are noted for high accumulation $\left(>200 \mathrm{Mg} \mathrm{ha}^{-1}\right.$ [megagrams per hectare]) of down logs and standing dead trees or snags (coarse woody debris, CWD; Harmon et al. 1986; Spies et al. 1988). The biomass of CWD changes predictably following forest fires, with peak 


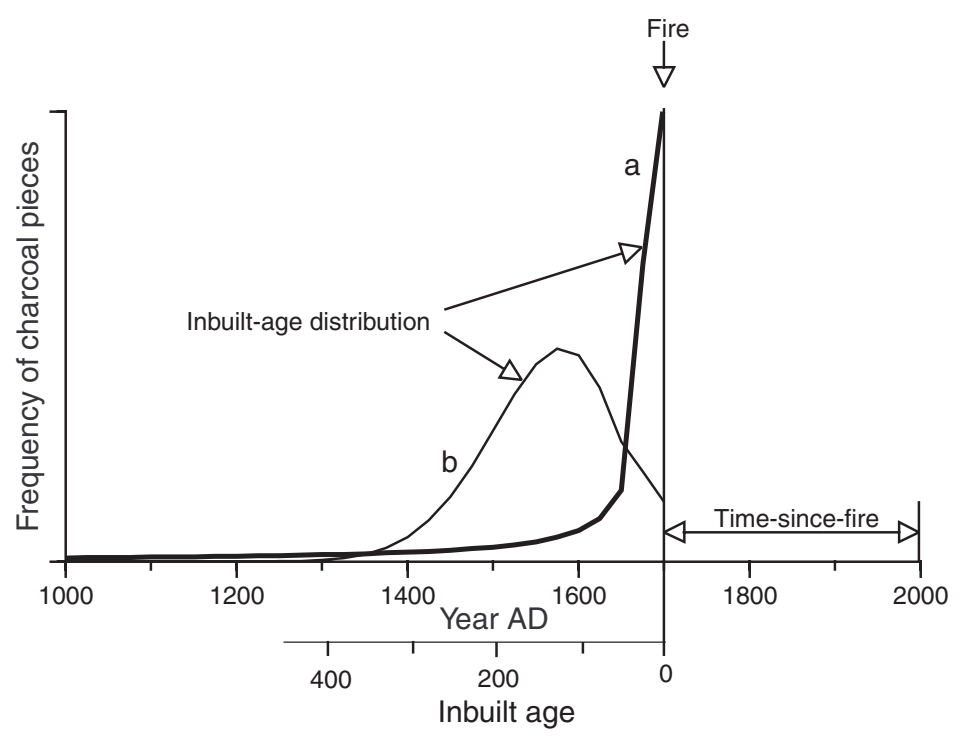

Figure 1 Schematic diagram showing terms associated with the inbuilt age of charcoal formed in a fire in AD 1700. The frequency of charcoal pieces across inbuilt ages can form a variety of inbuilt-age distributions. The two hypothetical inbuilt-age distributions shown here have different consequences for interpreting ${ }^{14} \mathrm{C}$ ages, as described in the text. Distribution (a) indicates inbuilt ages more than 50 years are rare; distribution (b) indicates inbuilt ages are frequently greater than 50 years.

accumulations occurring within few to several decades following fire due to mortality from the previous stand, and again after several centuries due to mortality of canopy trees in the new forest (Agee and Huff 1987; Spies et al. 1988). Long-term studies on CWD suggest that decay rates are speciesspecific and size-dependent, but follow a simple negative exponential curve (Harmon et al. 1986; Stone et al. 1998). Plot remeasurements on Vancouver Island suggest decay constants of 0.067 and $0.012 \mathrm{yr}^{-1}$ for Douglas-fir $\operatorname{logs}<20$ and $>80 \mathrm{~cm}$ in diameter, respectively (Stone et al. 1998). In the absence of large stand-replacing disturbances, CWD biomass should reach an equilibrium level controlled by rates of tree mortality and decay, though an equilibrium might not be reached until 1000 years following disturbance (Agee and Huff 1987).

Few forest fires have occurred in historical times in the Coastal Western Hemlock zone (Gavin 2000). These have been high-intensity events consuming dead wood as well as foliage and branches of living trees (Agee 1993). However, fuel consumption is generally a small proportion of the total stand biomass, because high moisture in the inner bark and sapwood prevents the combustion of live fuel with a diameter $>1 \mathrm{~cm}$ (Chandler et al. 1983; J K Agee, personal communication). Large CWD is also not completely consumed (Chandler et al. 1983; Stocks and Kauffman 1997). As a result, fuels are derived predominantly from a portion of CWD, litter (fine woody debris [FWD]), and small diameter branches $(<1 \mathrm{~cm})$. 


\section{METHODS}

\section{Inbuilt-Age Measurements}

\section{Rationale}

The inbuilt-age distribution for the study area was directly assessed by comparing the ${ }^{14} \mathrm{C}$ ages of soil charcoal pieces with the age of the most recent fire determined from tree-ring records. This analysis involved four steps: 1) forest fires at 16 locations were dated using tree-ring records, 2) surficial soil charcoal from these sites was dated (total of $26{ }^{14} \mathrm{C}$ ages), 3) each ${ }^{14} \mathrm{C}$ age was calibrated to yield a probability distribution, and 4) the probability distribution of each calibrated age was expressed relative to the known age of the fire, and all probability distributions were combined. This mean distribution was interpreted to represent the inbuilt-age distribution typical for these forests.

To estimate the inbuilt age of a charcoal sample collected at a given site, one would ideally need to know the probability distribution of inbuilt ages of all charcoal from a fire event at that site. Considering the expense of dating large numbers of charcoal pieces and the fact that inbuilt-age distributions are likely to vary across sites depending on fuel loads and fire behavior, it is impossible to construct such distributions for every site. The use of a composite probability distribution derived from data for several sites is a reasonable approach under these circumstances, as it should capture the potential range and central tendencies of inbuilt-age distributions that occur within a forest type.

\section{Field Methods}

I determined fire dates at 16 sites located $>200 \mathrm{~m}$ apart along an $8 \mathrm{~km}$ transect in low elevation forest ( $<200 \mathrm{~m}$ above sea level). At nine sites, I determined the exact year of fire based on tree-ring counts of western hemlock or Douglas-fir that regenerated following the fire (10-16 trees cored/site), in conjunction with abrupt growth changes recorded in 3-7 large Douglas-fir trees that survived the fire. The first year of abrupt growth change was the same among trees within a site, and was considered the year following the fire. At seven sites, I estimated fire dates based on the ages of at least seven dominant Douglas-fir. I estimated the age of each tree by extrapolating the age of the innermost ring in the core to the age of the pith (using concentric circles) and adding one year for every $15 \mathrm{~cm}$ of the core height above ground. The ages of Douglas-fir trees always clustered within 12-38 years at each site, suggesting that the fire date is close (ca. $10 \mathrm{yr}$ ) to the age of the oldest individual. If the date of a fire estimated by a stand age was very close to the year of a fire dated exactly at a nearby site, I used the exact-year date. For comparison with tree-ring dates of fires, I obtained 26 AMS ${ }^{14} \mathrm{C}$ ages on single pieces of charcoal collected from surficial soil at the 16 tree-ring sites (13 ages per site). I collected charcoal pieces as close to the soil surface as possible $(<5 \mathrm{~cm}$ from the soil surface) in an effort to date material originating from the most recent fire. At sites with $>1$ charcoal age determination (7 sites), locations of charcoal samples were about $5 \mathrm{~m}$ apart.

It is unlikely that the charcoal on the soil surface originated from a fire prior to the most recent fire dated by dendrochronology. Evidence from a set of 120 charcoal ${ }^{14} \mathrm{C}$ ages in the same study area suggests that either the organic horizon contained a charcoal stratigraphy of different fire events, or all the charcoal in the organic horizon originated from the same fire event (Gavin 2000). The latter case may occur if fires consume humus, causing charcoal from the most recent fire to be the most abundant. In this study, charcoal was always very abundant near the surface of undisturbed soils, suggesting the most recent fire was detected. However, this depositional environment is less ideal than other settings, such as burned ground surfaces that are not subject to bioturbation after burial by debris flow deposits shortly after the fire (Meyer et al. 1992, 1995). 


\section{Data Analysis}

${ }^{14} \mathrm{C}$ ages were calibrated (Stuiver and Reimer 1993 [v4.1]) with the INTCAL98 calibration curve (Stuiver et al. 1998). A calibrated ${ }^{14} \mathrm{C}$ age yields an irregular probability distribution that typically spans 100 to 500 years, depending on the standard error of the ${ }^{14} \mathrm{C}$ age and the position in the calibration curve (Stuiver and Reimer 1993). The first step in creating the composite inbuilt-age distribution was to express the individual calibrated-age distributions as years-before-fire (rather than years BP) by subtracting the tree-ring age of the fire from each age represented in the probability distribution. Then, individual distributions were summed from different sites into a mean probability distribution (MPD), weighting each ${ }^{14} \mathrm{C}$ age equally. Because only the general form of the MPD is important, I removed the high frequency variation with a LOWESS filter, a smoothing method using locally weighted regression, with a 200-year window. This smoothed MPD is regarded as an estimate of the inbuilt-age distribution.

\section{Inbuilt-Age Simulation Model}

\section{Rationale}

Simulation of inbuilt age may show the level of inbuilt age that is to be expected based on our current understanding of fire behavior and fuel loads. The simulation approach may also show what processes contribute the most to observed inbuilt ages. If the simulation results match observed values of inbuilt age, the simulation approach may be a reliable means of assessing inbuilt age that can be applied to other forest types. I simulated inbuilt-age distributions following fire events using measurements of fuel loads from plots in the study area (Pearson 2000), predictions of fuel consumption and charcoal production based on empirical studies (Sandberg and Ottmar 1983; Ottmar et al. 1993; Clark et al. 1998) and estimates of the time elapsed since the growth of woody fuels (Figure 2).

\section{Modeling Charcoal Production and Ages}

I calculated fuel loads from plots established in the Clayoquot Valley for a separate study of forest structure (data provided by A F Pearson; Pearson 2000). Plots were representative of three broad forest types: Sitka spruce forest (6 plots), cedar-hemlock forest (5 plots), and hemlock-fir forest (10 plots). The cedar-hemlock plots most closely resembled the species combination at sites used for direct measures of inbuilt age. CWD was assigned to one of five decay classes, where decay class I represents recently dead trees with small twigs not yet decayed and decay class V represents wood rotten throughout with no structural integrity (Sollins et al. 1987). In each plot, I calculated CWD volume using equations for a cylinder for logs, or a cone with a taper ratio of 0.012 for standing snags (Spies et al. 1988). I calculated CWD biomass using wood density estimates of species in different decay classes, which ranged from $0.43 \mathrm{~g} \mathrm{~cm}^{-3}$ for decay class I Sitka spruce to $0.13 \mathrm{~g} \mathrm{~cm}^{-3}$ for decay class V western hemlock (Graham and Cromack 1982; Sollins 1982; Spies et al. 1988). If a piece of CWD was not identifiable to species, I randomly assigned it to a species using the proportions of identified CWD in the plot. I assumed smaller diameter fuel loads (i.e. forest floor litter) to be $10 \mathrm{Mg} \mathrm{ha}^{-1}$ for all plots, a value from similar stands (Agee and Huff 1987). I estimated live branch biomass for all trees in each plot (Pearson 2000) using species-specific allometric equations in Gholz et al. (1979), of which 5\% was considered available fuel $<1 \mathrm{~cm}$ diameter (approximate proportion from coastal old-growth Douglas-fir; Ishii et al. 2000).

I calculated CWD fuel consumption using an empirically derived relationship in which moisture of 1000-hour time-lag fuel (CWD 7.6-15.2 cm diameter) predicts diameter reduction (Sandberg and 


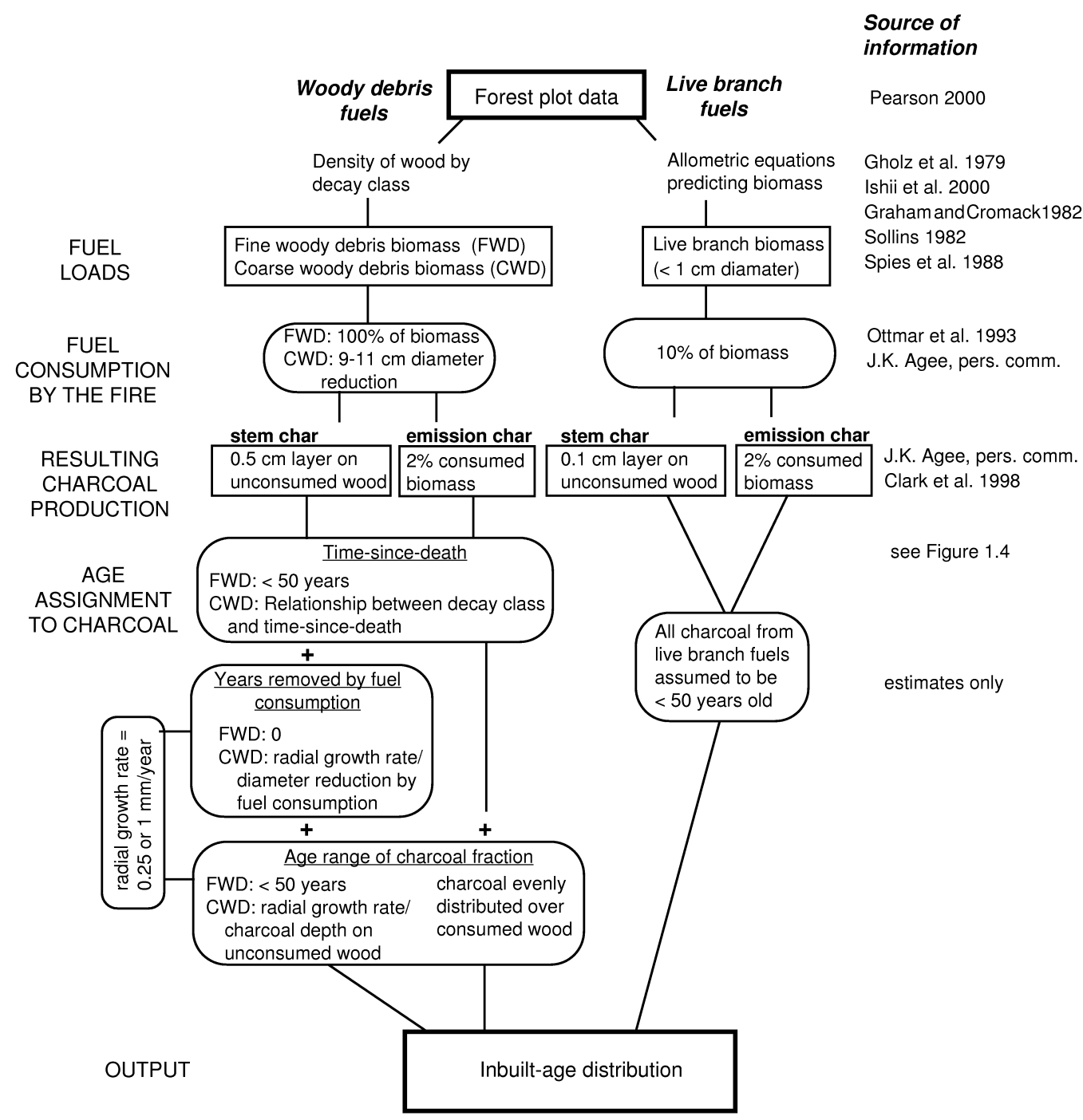

Figure 2 Outline of the steps used to simulate the inbuilt-age distribution of charcoal following forest fire in western Washington and British Columbia.

Ottmar 1983; Ottmar et al. 1993). This relationship, developed for summer-like (i.e. dry, late season) burning conditions, predicts diameter reduction in inches, $\mathrm{C}$, as

$$
\mathrm{C}=-0.125 \times(\% \text { 1000-hour fuel moisture })+6.27
$$

Conditions necessary for wildfire in coastal forests of western British Columbia require moisture of the 1000-hour time-lag fuel class to drop below $20 \%$, conditions usually met only after several weeks of no rain within summers of below-average rainfall (Huff and Agee 1980; Pickford et al. 1980). I used two fuel moisture levels, $15 \%$ and $21 \%$, corresponding to $11 \mathrm{~cm}$ and $9 \mathrm{~cm}$ diameter reduction, respectively. I assumed decay class V CWD and FWD $(<2.5 \mathrm{~cm}$ diameter) were completely consumed (J K Agee, personal communication). I also assumed fire intensity to be high, 
causing crown fires, consuming $10 \%$ of live branch biomass $<1 \mathrm{~cm}$ diameter, but no live fuels $>1 \mathrm{~cm}$ diameter (Fahnestock and Agee 1983).

I calculated charcoal production from CWD as a $0.5 \mathrm{~cm}$ layer on unconsumed wood, and from a portion ( $2 \%$ by mass) of all consumed fuels that was lifted off the fire by convection ( $\mathrm{J}$ K Agee, personal communication; Clark et al. 1998). Crown fuels have a greater moisture content, do not burn as long as understory fuels, and therefore should produce a more shallow charcoal layer on branch wood. I calculated charcoal production from small diameter live branches as a $0.1 \mathrm{~cm}$ layer, assuming an average branch diameter of $0.5 \mathrm{~cm}$ following fire (equivalent to charcoal comprising $36 \%$ by volume of unconsumed small-diameter branches).

The inbuilt age of charcoal differs among fuel types. For CWD fuels, the inbuilt age of charcoal is affected by its residence time following death, depth of consumption of the outer wood, and the diameter growth rate of the outer consumed wood. I obtained species-specific residence time estimates from studies that measured the time-since-death of CWD in different stages of decay (Graham and Cromack 1982; Sollins et al. 1987; Hennon and Loopstra 1991; Daniels et al. 1997). These studies used tree-ring analysis and ${ }^{14} \mathrm{C}$ ages to measure the time-since-death of individual pieces of CWD. Because western redcedar CWD decays more slowly than other species (Daniels et al. 1997), the age of older western redcedar CWD has rarely been studied and western redcedar comprises a large proportion of the CWD in the study area, I obtained three ${ }^{14} \mathrm{C}$ ages from the last ten years of growth on decay class 4 and 5 western redcedar snags (Table 1). Together, these various studies indicate that both the average time-since-death and range of times-since-death of CWD increase exponentially with decay class (Figure 3; see also Harmon et al. 1986). Time-since-death estimates for Pacific silver fir were not available in the literature, and were assumed to be the same as for western hemlock, a species with similar wood properties (Hoadley 1990). I assumed live branch fuels and FWD to be less than 50 years old.

Table $1{ }^{14} \mathrm{C}$ ages on intact wood taken directly beneath the bark of three different standing western redcedar snags. The snags are in an advanced state of decay, snapped off at around $5 \mathrm{~m}$ above the ground with little remaining bark and rotten portions reaching the center of the tree.

\begin{tabular}{llccc}
\hline $\begin{array}{l}\text { Decay } \\
\text { class }\end{array}$ & $\begin{array}{l}\text { Lab code } \\
(\text { CAMS \#) }\end{array}$ & $\delta^{13} \mathrm{C}(\%)$ & ${ }^{14} \mathrm{C}$ age $(\mathrm{BP})$ & cal AD $(1 \sigma)^{\mathrm{a}}$ \\
\hline IV & 43866 & -22.24 & $270 \pm 60$ & $1645(1516-1796)$ \\
IV & 43871 & -22.68 & $490 \pm 60$ & $1430(1334-1463)$ \\
V & 43886 & -20.86 & $950 \pm 50$ & $1143(1025-1156)$ \\
\hline \multicolumn{4}{l}{ Median age intercept and lower and upper limits of cal age ranges only }
\end{tabular}

Radial growth rate $(\mathrm{G})$ and diameter reduction from fuel consumption $(\mathrm{C})$ determine the number of years of growth removed from the outer wood by fire. Therefore, these parameters control the effect of fuel consumption on inbuilt age. To simplify interpretation, I ran two scenarios in which $\mathrm{G}$ and $\mathrm{C}$ were assumed to be constant over the plot. The first scenario (fast-growth) assumes 45 years removed by consumption $\left(\mathrm{G}=1 \mathrm{~mm} \mathrm{yr}^{-1} ; \mathrm{C}=9 \mathrm{~cm}\right)$. The second scenario (slow-growth) assumes 220 years removed by consumption $\left(\mathrm{G}=0.25 \mathrm{~mm} \mathrm{yr}^{-1} ; \mathrm{C}=11 \mathrm{~cm}\right)$. For each piece of CWD, I calculated the amount of charcoal in each of five age classes (0-50, 50-100, 100-200, 200-400, 400$1000 \mathrm{yr}$ ) based on the sum of the time-since-death (Figure 3), the number of years removed by fuel consumption, and the number of years comprising the $0.5 \mathrm{~cm}$ layer of charcoal on the unconsumed 
wood. Charcoal was also produced from $2 \%$ of the consumed biomass (Figure 2); this charcoal was assumed to be evenly distributed over the consumed wood. The time-since-death estimates may range several decades to centuries for individual pieces of CWD, causing the inbuilt ages to encompass more than one age class; in these cases charcoal was divided among age classes based on the proportion of the estimated age range in each age class.

In addition to the two main scenarios of the model described above, I ran additional scenarios to examine the sensitivity of the inbuilt-age distribution to several parameters. In these scenarios, I varied the radial growth rate $\left(0.1-2 \mathrm{~mm} \mathrm{yr}^{-1}\right)$, diameter reduction by fuel consumption $(5-15 \mathrm{~cm})$, the depth of the charcoal layer on CWD $(0.1-1 \mathrm{~cm})$ or live branches $(0.05-0.5 \mathrm{~cm})$, and the percentage of consumed wood contributing to emission charcoal $(0.5-10 \%)$. To examine the sensitivity of the model output on each variable, I kept all other variables constant using the values in the slow-growth scenario (above), and recorded the proportion of charcoal produced in ages classes $>200$ years.

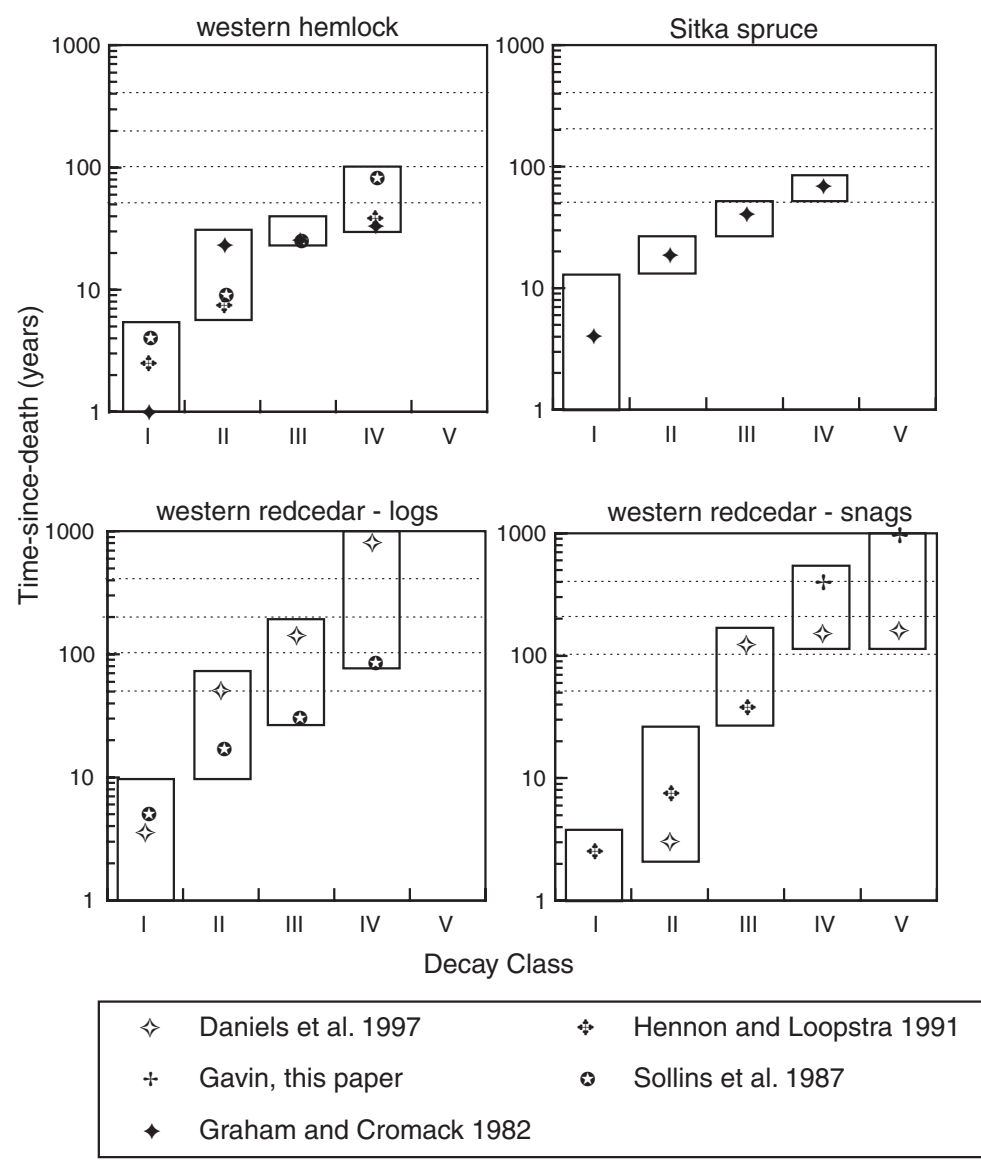

Figure 3 Time-since-death of coarse woody debris and snags of common tree species in western Washington, British Columbia, and southeast Alaska. Data were limited to studies that directly measured time-since-death using tree-ring analysis on the fallen tree or on neighboring trees affected by the death of the tree, by plot remeasurements, or by ${ }^{14} \mathrm{C}$ age determinations. Solid rectangles represent the time-sincedeath ranges of coarse woody debris and snags used in this study. Dashed lines indicate classes used to summarize the simulation results. 


\section{RESULTS}

\section{Inbuilt-Age Measurements}

The 26 calibrated ${ }^{14} \mathrm{C}$ ages of charcoal overestimated the age of the fire between 0 and 670 years (Table 2; Figure 4). The majority of the ${ }^{14} \mathrm{C}$ ages (21) had inbuilt ages between 150 and 450 years; but two ${ }^{14} \mathrm{C}$ ages yielded inbuilt ages over 600 years. Several tree-ring dated fire events occurred during an "ambiguous" portion of the calibration curve in the 19th century, though ${ }^{14} \mathrm{C}$ ages from these fires calibrated to a period prior to this ambiguous region (Figure 4). Inbuilt ages of charcoal from 19th century fires (average $=354 \mathrm{yr}$ ) were generally greater than inbuilt ages of charcoal from earlier fires (average $=193 \mathrm{yr}$ ) $\left(\right.$ Table 2 ). The MPD of the calibrated ${ }^{14} \mathrm{C}$ ages, expressed relative to the age of the fire, peaks at 200 years $($ median $=270 \mathrm{yr} ; 25 \mathrm{th}-75 \mathrm{th}$ percentile $=180-380 \mathrm{yr} ; 5$ th $-95 \mathrm{th}$ percentile $=30-610 \mathrm{yr}$ ) (Figure 5). Overall, the composite curve implies that $69 \%$ of the charcoal overestimates the time-since-fire by $>200$ years, and $22 \%$ of the charcoal overestimates the timesince-fire by $>400$ years.

\section{Inbuilt-Age Simulation Model}

Measured CWD and estimated small branch fuel loads varied widely among plots (77-1060 and 1.5$16.3 \mathrm{Mg} \mathrm{ha}^{-1}$, respectively), but the average fuel loads were similar among forest types (169-180 and 6.1-7.0 $\mathrm{Mg} \mathrm{ha}^{-1}$, respectively) (Figure 6). Likewise, simulated CWD fuel consumption varied considerably among plots (12-47\%), but the average was similar among forest types (25-31\%). An average of $6.2 \mathrm{Mg} \mathrm{ha}^{-1}$ of wood biomass was converted to charcoal in each plot $\left(3.8-12.9 \mathrm{Mg} \mathrm{ha}^{-1}\right)$, with charcoal from CWD the major source of charcoal in each plot (average 90\%; 67-98\%). Increasing the CWD diameter reduction from 9 to $11 \mathrm{~cm}$ caused fuel consumption to increase by $4 \%$ and charcoal mass to decrease by $3 \%$.

The simulated inbuilt-age distributions varied greatly between the two model scenarios (Figure 7). The fast growth scenario produced almost no charcoal in the $>100$-year age classes, but the slow growth scenario produced $85 \%$ and $25 \%$ of the charcoal in the $>200$ and $>400$-year age classes, respectively. In contrast to the large differences between model scenarios, inbuilt-age distributions were similar within and among forest types, nearly always peaking in the same age class. Most variability within forest types was in the $<50$-year age classes.

Sensitivity analysis of the model output indicated that the magnitude of inbuilt age was mainly affected by the combined effect of radial growth rate and depth of consumption of outer wood. The proportion of charcoal in age classes $>200$ years increased from very low (ca. $5 \%$ ) to high (ca. $90 \%$ ) levels when parameters for growth rates and/or fuel consumption were increased to result in about 200 years of outer wood removed by fuel consumption. In contrast, the proportion of charcoal in age classes $>200$ years changed by $<10 \%$ when varying the parameters for the depth of charcoal on unconsumed wood or the parameter for the proportion of consumed wood contributing to emission charcoal.

\section{DISCUSSION}

\section{Implications of the Inbuilt-Age Error}

The error introduced by inbuilt age potentially affects the interpretation of fire dates in the study area because the magnitude of these errors typically exceeds the $2 \sigma$ confidence interval of a calibrated age distribution. In all but one case, the ${ }^{14} \mathrm{C}$ ages of soil charcoal are significantly greater than the actual age of the fire, suggesting that inbuilt ages of charcoal in the watershed are often $>180$ years 
Table $2{ }^{14} \mathrm{C}$ ages of soil charcoal in the Clayoquot Valley. Charcoal was collected from near the soil surface at sites where tree-ring dates of the fire were possible.

\begin{tabular}{|c|c|c|c|c|c|c|}
\hline $\begin{array}{l}\text { Site number and } \\
\text { tree-ring method }\end{array}$ & $\begin{array}{l}\text { Year of fire } \\
\text { (AD) }\end{array}$ & $\begin{array}{l}\text { Lab code } \\
(\text { CAMS \#) }\end{array}$ & $\begin{array}{l}\delta^{13} C^{a} \\
(\% o)\end{array}$ & $\begin{array}{c}{ }^{14} \mathrm{C} \text { age } \\
(\mathrm{BP})\end{array}$ & cal AD $(1 \sigma)^{\mathrm{b}}$ & $\begin{array}{c}\text { Inbuilt age } \\
\text { (years) }^{\mathrm{c}}\end{array}$ \\
\hline (1) Stand age & 1550 & 32248 & -25.87 & $320 \pm 60$ & 1557 (1498-1640) & 0 \\
\hline (2) Stand age & 1550 & 53499 & & $610 \pm 50$ & 1350 (1305-1395) & 200 \\
\hline (3) Stand age & $\begin{array}{l}1620 \\
1620 \\
1620\end{array}$ & $\begin{array}{l}53473 \\
53474 \\
32339\end{array}$ & -28.50 & $\begin{array}{l}420 \pm 50 \\
450 \pm 50 \\
520 \pm 60\end{array}$ & $\begin{array}{l}1448(1430-1614) \\
1441(1419-1478) \\
1416(1326-1443)\end{array}$ & $\begin{array}{l}172 \\
179 \\
204\end{array}$ \\
\hline (4) Stand age & $\begin{array}{l}1655 \\
1655 \\
1655\end{array}$ & $\begin{array}{l}32239 \\
53482 \\
53483\end{array}$ & -26.74 & $\begin{array}{l}350 \pm 60 \\
440 \pm 60 \\
970 \pm 50\end{array}$ & $\begin{array}{l}1599(1481-1631) \\
1443(1414-1613) \\
1029(1017-1156)\end{array}$ & $\begin{array}{r}56 \\
212 \\
626\end{array}$ \\
\hline (5) Growth response & 1683 & 43899 & -23.1 & $370 \pm 60$ & $1486(1455-1626)$ & 197 \\
\hline (6) Stand age & 1683 & 43914 & -27.43 & $340 \pm 50$ & $1594(1491-1631)$ & 89 \\
\hline (7) Growth response & 1805 & 32342 & -23.67 & $530 \pm 60$ & 1412 (1324-1439) & 393 \\
\hline (8) Stand age & $\begin{array}{l}1805 \\
1805\end{array}$ & $\begin{array}{l}39387 \\
32343\end{array}$ & -27.81 & $\begin{array}{l}410 \pm 40 \\
430 \pm 60\end{array}$ & $\begin{array}{l}1452(1437-1628) \\
1445(1422-1614)\end{array}$ & $\begin{array}{l}353 \\
360\end{array}$ \\
\hline (9) Stand age & 1805 & 53481 & & $310 \pm 60$ & $1545(1503-1646)$ & 260 \\
\hline (10) Growth response & $\begin{array}{l}1805 \\
1805 \\
1805\end{array}$ & $\begin{array}{l}43873 \\
43875 \\
43876\end{array}$ & $\begin{array}{l}-24.40 \\
-23.93 \\
-23.94\end{array}$ & $\begin{array}{l}350 \pm 40 \\
350 \pm 40 \\
420 \pm 50\end{array}$ & $\begin{array}{l}1599(1485-1630) \\
1599(1485-1630) \\
1448(1430-1614)\end{array}$ & $\begin{array}{l}206 \\
206 \\
357\end{array}$ \\
\hline (11) Growth response & $\begin{array}{l}1830 \\
1830\end{array}$ & $\begin{array}{l}32233 \\
32234\end{array}$ & $\begin{array}{l}-24.22 \\
-27.31\end{array}$ & $\begin{array}{l}420 \pm 60 \\
510 \pm 90\end{array}$ & $\begin{array}{l}1448(1430-1615) \\
1421(1311-1472)\end{array}$ & $\begin{array}{l}382 \\
409\end{array}$ \\
\hline (12) Growth response & 1872 & 32348 & -23.35 & $320 \pm 60$ & $1557(1498-1640)$ & 315 \\
\hline (13) Growth response & $\begin{array}{l}1872 \\
1872\end{array}$ & $\begin{array}{l}32231 \\
32232\end{array}$ & $\begin{array}{l}-23.60 \\
-23.26\end{array}$ & $\begin{array}{l}390 \pm 50 \\
490 \pm 60\end{array}$ & $\begin{array}{l}1476(1443-1621) \\
1430(1334-1463)\end{array}$ & $\begin{array}{l}396 \\
442\end{array}$ \\
\hline (14) Growth response & 1872 & 43921 & -22.31 & $500 \pm 50$ & $1426(1337-1447)$ & 446 \\
\hline (15) Growth response & 1872 & 43922 & -22.47 & $230 \pm 50$ & $1659(1635-1943)$ & 213 \\
\hline (16) Growth response & $\begin{array}{l}1886 \\
1886\end{array}$ & $\begin{array}{l}43870 \\
53472 \\
\end{array}$ & -21.87 & $\begin{array}{l}850 \pm 50 \\
300 \pm 50\end{array}$ & $\begin{array}{l}1212(1074-1260) \\
1637(1517-1650)\end{array}$ & $\begin{array}{l}674 \\
249\end{array}$ \\
\hline
\end{tabular}

assumed to be $-25 \%$ where not measured

${ }^{b}$ Median age intercept and lower and upper limits of cal age ranges only

${ }^{\mathrm{c}}$ Calculated as the difference between the fire year and the median cal age intercept

( 25 th percentile) and $<610$ years ( 95 th percentile), though some may be as large as 670 years (greatest observed value) (Figure 5). Such potentially large errors in estimating a fire date can prevent the correlation of a fire date with other short-lived events. For example, a large inbuilt age limits the ability to correlate fire dates with known climatic periods of $<300$ years. On the other hand, a certain amount of inbuilt age may be acceptable in some studies. For example, to claim that a piece of charcoal represents a fire that burned at least 1000 years ago, the age of charcoal should exceed 1000 years by the maximum inbuilt age that is likely to be encountered. The present study suggests that ${ }^{14} \mathrm{C}$ ages would have to be $>1610$ cal BP to claim that fires have not burned in the last 1000 years.

The inbuilt-age error also affects the minimum interval between fires that can be detected with ${ }^{14} \mathrm{C}$ ages of charcoal. For example, two fires that occur 300 years apart may produce charcoal with the same ${ }^{14} \mathrm{C}$ age. Similarly, two calibrated ${ }^{14} \mathrm{C}$ ages from charcoal pieces at a given location can differ 
by 300 years (suggesting a fire interval of ca. $300 \mathrm{yr}$ ), though both pieces of charcoal actually originated from the same fire event. Thus, it is impossible to determine whether two ${ }^{14} \mathrm{C}$ ages originated from the same fire or from different fires if the dates differ by less than the maximum inbuilt age. However, in cases where there is stratigraphic evidence suggesting different fires (e.g. two charcoal lenses in an organic soil), the effect of inbuilt age is to increase the error of the fire interval estimate.

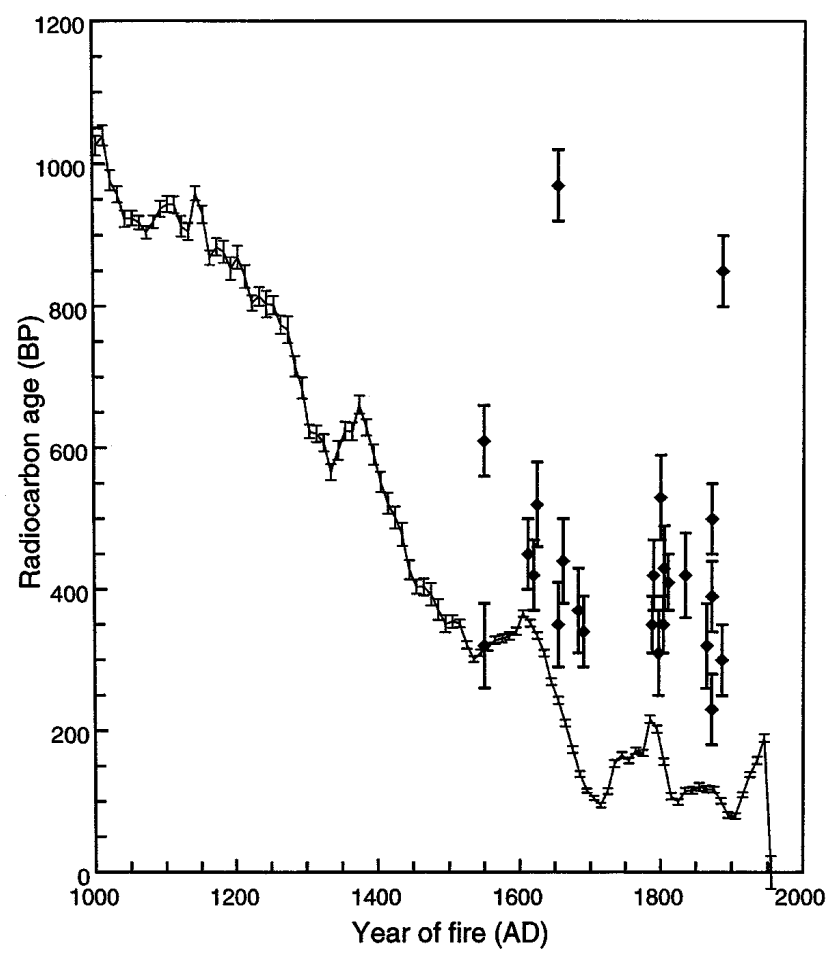

Figure $4{ }^{14} \mathrm{C}$ ages $( \pm 1 \sigma)$ on single fragments of charcoal from the soil surface from the Clayoquot Valley, Vancouver Island. The ages are plotted on the known date of the fire determined from tree-ring records from the immediate vicinity. Multiple ages from the same fire year are offset slightly for clarity. The inbuilt age of each ${ }^{14} \mathrm{C}$ age is the horizontal distance from the sample to the calibration curve (INTCAL98; Stuiver et al. 1998).

\section{Simulation of Inbuilt Age}

The simulations used many parameters to capture the key processes affecting the inbuilt-age distribution (Figure 2). The estimates of fuel loads and fuel consumption used in the simulations are similar to loads estimated in other studies from the Pacific Northwest (Fahnestock and Agee 1983; Agee and Huff 1987; Spies et al. 1988; Stocks and Kauffman 1997). However, the parameters used for charcoal production and the assignment of inbuilt age to charcoal are only estimates because few studies are available against which to calibrate these values. For example, no studies have estimated the total quantity of charcoal produced in a fire, or the amount of charcoal from different types of fuel. Furthermore, the radial growth rates of the wood consumed by fire, which have a large effect on inbuilt age, are variable within and among trees and therefore were difficult to incorporate into the simulation model. 


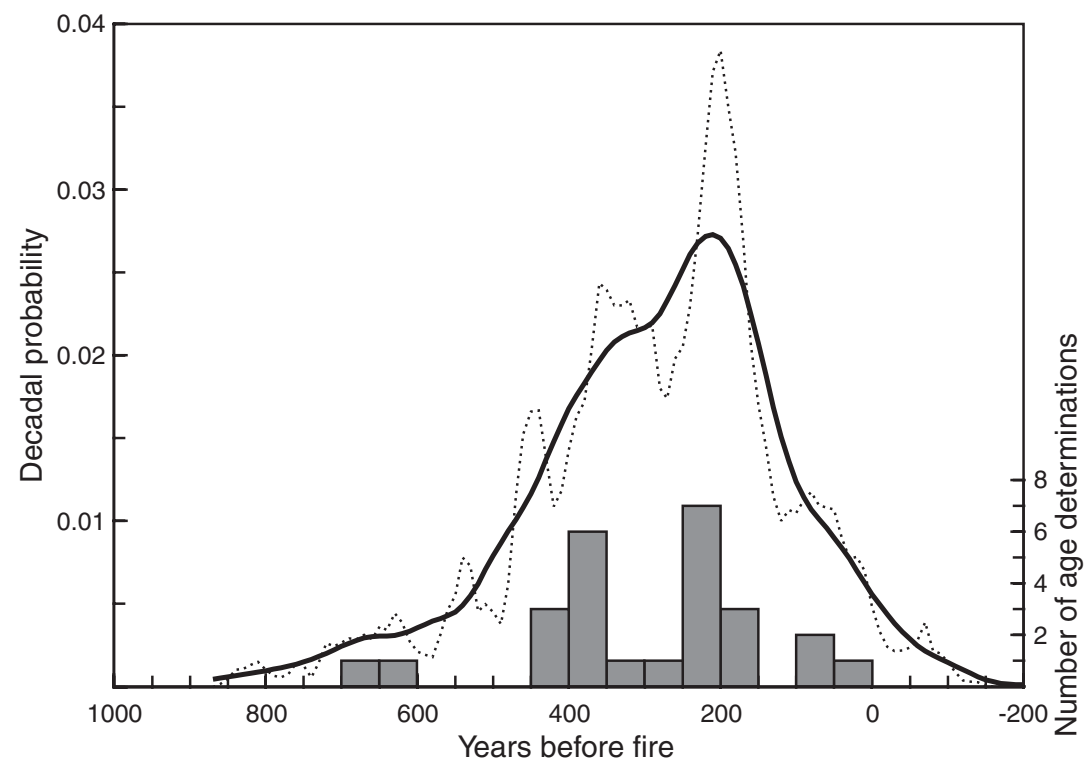

Figure 5 Mean probability distribution (MPD) of 26 calibrated ${ }^{14} \mathrm{C}$ ages of soil charcoal. The known ages of fire were subtracted from each age in the calibrated age probability distributions before combining into the MPD. The MPD (dashed line) was smoothed using a LOWESS filter with a 200 year window (solid line). The distribution of the calibrated age intercepts is shown with gray bars.

Despite these uncertainties, parameter estimations of several simulated inbuilt-age distributions resembled the measured inbuilt ages (i.e. similar proportions of charcoal were $>200$ and $>400$ years old; Figures 5 and 7). These scenarios assumed that the majority of charcoal originates from CWD, the growth rate of the outer consumed portions of fuels is slow $\left(0.25 \mathrm{~mm} \mathrm{yr}^{-1}\right)$, and there is a large diameter reduction due to fuel consumption $(11 \mathrm{~cm})$. This set of conditions is reasonable, given the forest structure and expected fire behavior in the Clayoquot Valley. Although fires in this region typically kill most trees, crown fires are very patchy (Agee 1993). At some sites, high moisture in crown foliage may result in very little combustion of crown fuel, resulting in even less charcoal in the younger age classes than used in this simulation. In contrast, fire duration and intensity in the understory may be sufficient to completely consume FWD and the outer wood of CWD. Slow, smoldering fires in dead wood and forest floor material can continue for days to weeks after the passing of the fire line, and thus produce a large quantity of charcoal from CWD (Chandler et al. 1983).

In coastal temperate rain forests such as the Clayoquot Valley, the charcoal produced from CWD may be centuries old. Western redcedar, one of the most common species in the study area, is more resistant to decay than other species (Figure 3; Daniels et al. 1997). The slow decay of this species may explain the two ${ }^{14} \mathrm{C}$ ages that suggest inbuilt ages of about $600-700$ years (Figure 5). In addition, most charcoal probably originates from inner (older) layers of CWD because the outer sapwood decays more rapidly than the inner heartwood and can slough off within a few decades of tree death. Thus processes of decay, fragmentation, and consumption by fire cause little of the outer wood to turn into charcoal. Contributing further to a large inbuilt age, this outer wood can represent more than a century of tree-ring growth because large CWD is derived from canopy-dominant trees that often persist for centuries with slow radial growth (e.g. DeBell and Franklin 1987). For exam- 


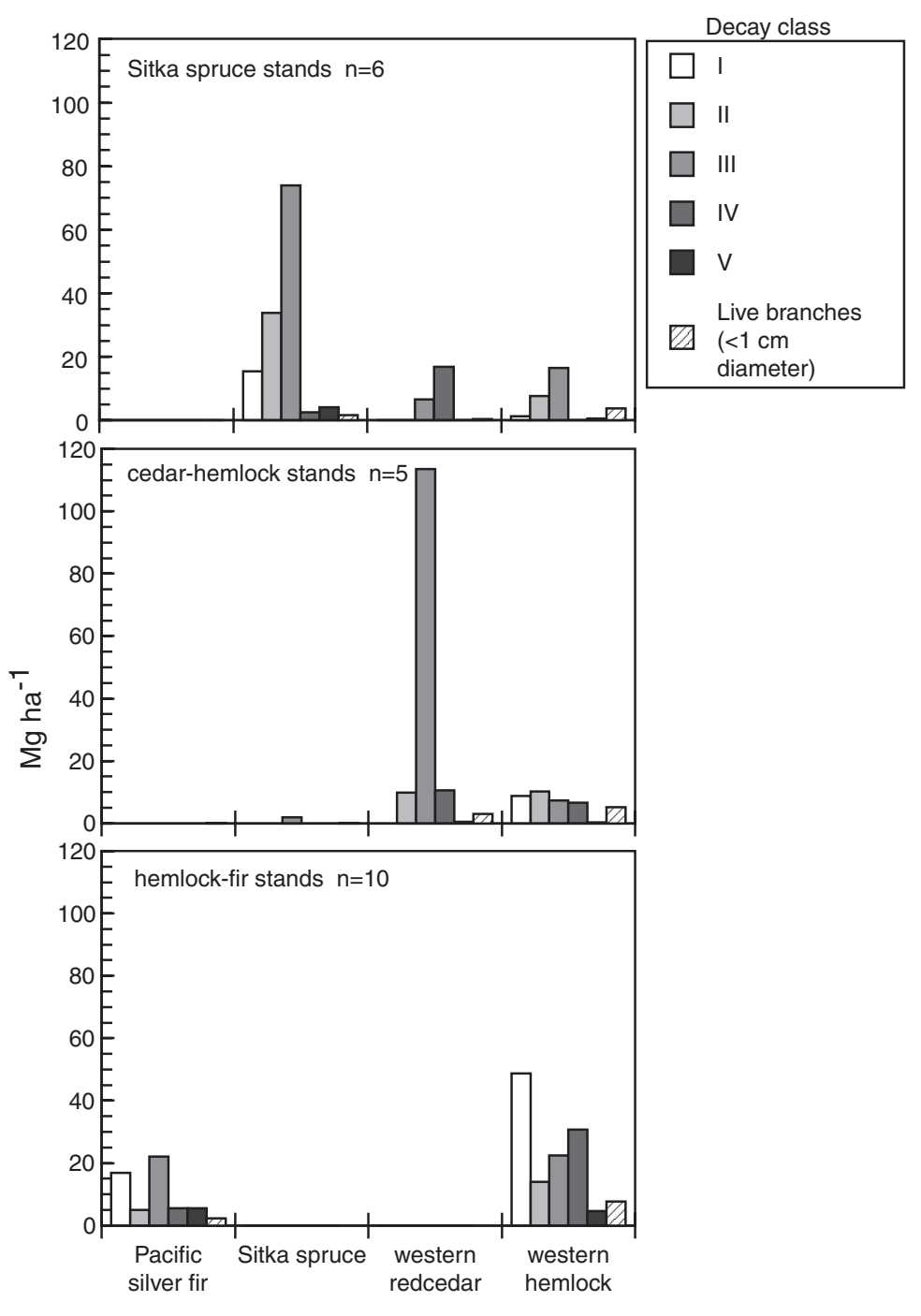

Figure 6 Mean coarse woody debris and fine branch biomass of plots in three forest types in the Clayoquot Valley (plot measurements from Pearson 2000).

ple, the outer $5 \mathrm{~cm}$ of wood of 130 large Douglas-fir and western hemlock trees cored in the Clayoquot Valley contained an average of 125 years $\left(0.4 \mathrm{~mm} \mathrm{yr}^{-1}\right.$; D Gavin, unpublished data).

\section{Sampling Strategies and Quantitative Treatment of the Inbuilt-Age Error}

Given that inbuilt ages might have large effects on determining ages of fires, what methods can aid the interpretation of such charcoal ${ }^{14} \mathrm{C}$ ages? Two different strategies discussed below may be used to help reduce inbuilt age, or to statistically treat ${ }^{14} \mathrm{C}$ ages to better reflect inbuilt age. First, inbuilt age may be reduced by determining the ${ }^{14} \mathrm{C}$ ages of several charcoal pieces and using the minimum age as the best estimate of the fire event. Second, an estimate of the inbuilt-age distribution may be incorporated into the error of a calibrated ${ }^{14} \mathrm{C}$ age such that the new, adjusted error encompasses the age of the fire. 


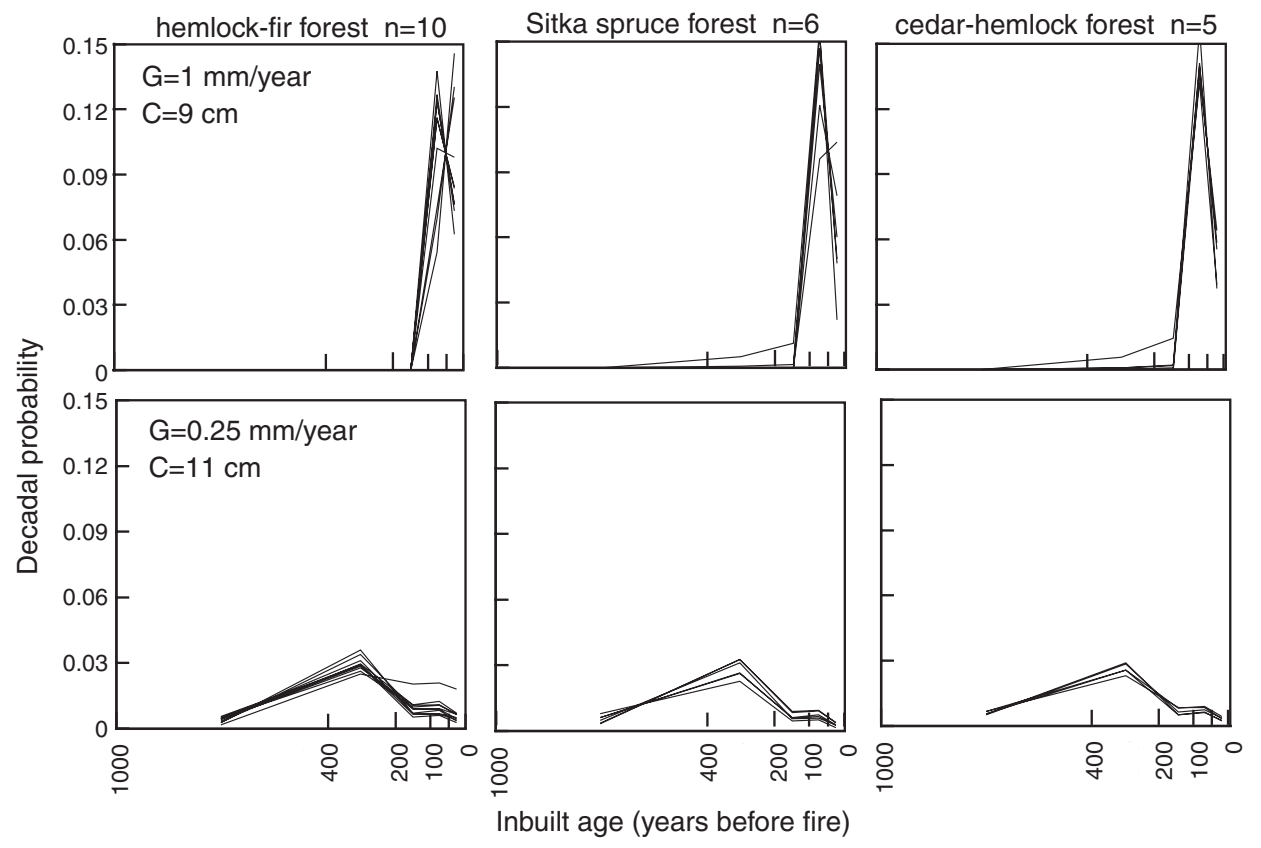

Figure 7 Simulated inbuilt-age distributions of charcoal biomass produced following forest fire in the Clayoquot Valley. Each line represents the charcoal age distribution for a forest plot. Two scenarios are shown for different diameter growth rates $(\mathrm{G})$ and diameter reduction by fuel consumption $(\mathrm{C})$.

\section{Using Several ${ }^{14} \mathrm{C}$ Ages to Minimize Inbuilt Age}

If the minimum of several charcoal ${ }^{14} \mathrm{C}$ ages at a site is selected as the best estimate of the age of a fire, then the minimum ${ }^{14} \mathrm{C}$ age would have, on average, a lower inbuilt age than that of a single ${ }^{14} \mathrm{C}$ age. However, if charcoal with little inbuilt age is rare, obtaining several ${ }^{14} \mathrm{C}$ ages would have limited potential for reducing the inbuilt age. For example, of the $26{ }^{14} \mathrm{C}$ ages of charcoal used in the present study, only three $(11 \%)$ had inbuilt ages $<100$ years (Figure 5$)$. With this proportion of charcoal pieces with small inbuilt ages, the ages of six pieces of charcoal must be determined to ensure a $50 \%$ probability of obtaining one ${ }^{14} \mathrm{C}$ age with $<100$-year inbuilt age (i.e. 1 - the probability that six randomly chosen charcoal pieces have inbuilt ages $>100$ years $\left.=1-(23 / 26)^{6}=0.52\right)$. Given the expense of AMS dates, most researchers could not afford six ${ }^{14} \mathrm{C}$ ages for each fire event. The alternative of using fewer ${ }^{14} \mathrm{C}$ ages does not significantly reduce this error. Therefore, for studies in similar forest types, researchers must weigh the importance of reducing the inbuilt-age error against the number of fire events that need to be dated. In other forest types where inbuilt-age errors are likely to be smaller (see below), somewhat fewer ${ }^{14} \mathrm{C}$ ages may yield accurate results.

\section{Adjusting Calibrated ${ }^{14} \mathrm{C}$ Ages to Reflect the Uncertainty Due to Inbuilt Age}

The inbuilt-age distribution obtained in this study is used to describe the range and relative abundance of inbuilt ages expected for charcoal produced by fires in the forests of the study area. Thus it also represents the probability distribution of inbuilt age associated with a randomly chosen piece of charcoal. This distribution can, therefore, be added to the error of a calibrated ${ }^{14} \mathrm{C}$ age, resulting in a wider distribution that more accurately shows the error of the ${ }^{14} \mathrm{C}$-derived estimate of the fire date. This adjustment is calculated as a weighted moving average of the probability distribution of a cal- 
ibrated ${ }^{14} \mathrm{C}$ age using the inbuilt-age distribution as the set of weights. The probability distribution of a calibrated ${ }^{14} \mathrm{C}$ age, $P(T)$ (in years $\mathrm{AD} / \mathrm{BC}$ ), adjusted for inbuilt age is calculated as

$$
P_{a d j}(T)=\sum_{i=m}^{n} W(i) \cdot P(T-i)
$$

where $P_{a d j}(T)$ is the probability distribution of the adjusted age, $W(i)$ is the inbuilt-age distribution ranging from $m$ to $n$ years before fire, and $\Sigma W(i)=1$. Calibrated ${ }^{14} \mathrm{C}$ ages adjusted for inbuilt age will have a lower median age and a larger error than unadjusted calibrated dates (Figure 8).
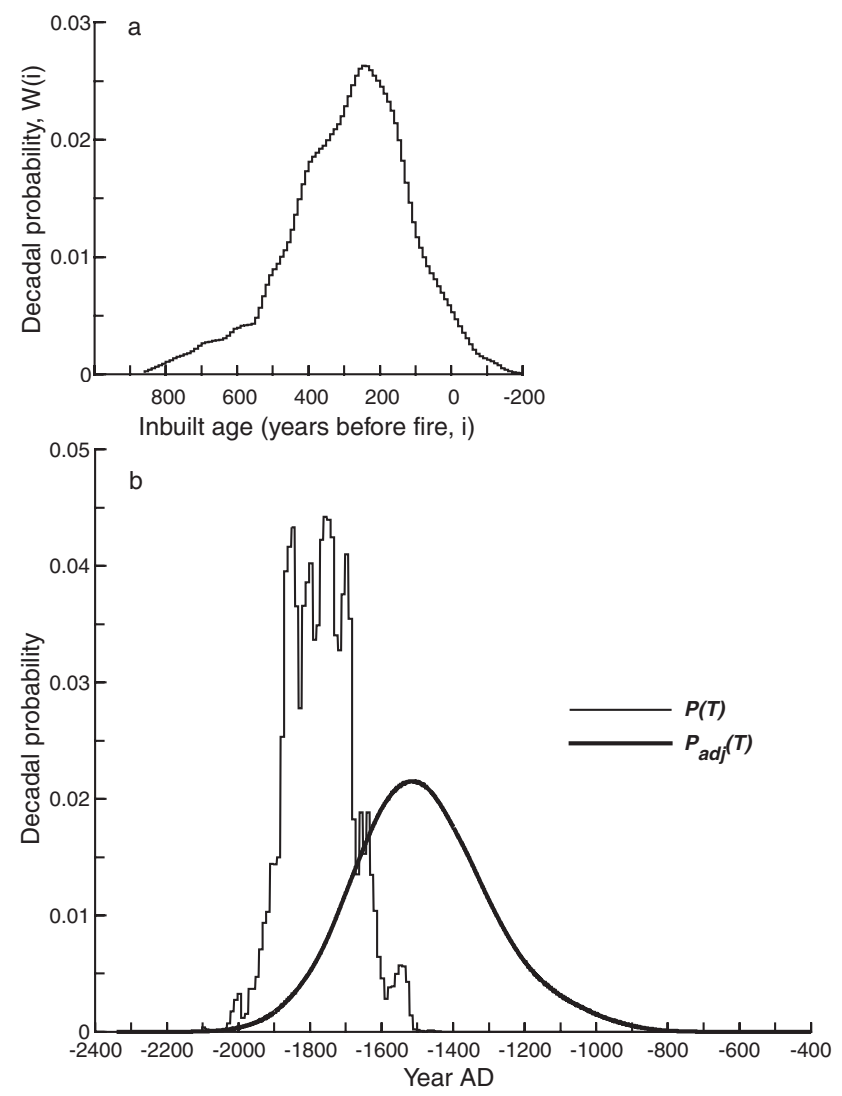

Figure 8 Example of a ${ }^{14} \mathrm{C}$ age determination adjusted to account for inbuilt age. a. A smoothed inbuilt-age distribution determined from 26 ${ }^{14} \mathrm{C}$ dates (see Figure 5). b. Probability distribution of a calibrated ${ }^{14} \mathrm{C}$ date $(3460 \pm 70 \mathrm{BP})$ before $(P(T))$ and after $\left(P_{a d j}(T)\right)$ adjustment for inbuilt age using the values in (a) as weights in a weighted moving average filter.

Adjusting ${ }^{14} \mathrm{C}$ ages is an explicit means of uniformly applying error from inbuilt age to all ${ }^{14} \mathrm{C}$ ages in a study. Using the $P_{a d j}(T)$ distribution incorporates the range of expected inbuilt ages into the final estimate of the fire date, and, therefore, graphically shows the uncertainty of the estimate of the fire date (Figure 8). The adjusted probability distribution can be used in statistical tests that compare fire dates. For example, it provides a means of determining whether the effect of inbuilt age causes two 
estimates of fire dates to overlap, and thus whether the two charcoal pieces originated from the same fire. One caveat with this method occurs, however, because the adjusted probability distribution is only as reliable as the inbuilt-age distribution on which it is based. As a result of the uncertainty in defining inbuilt-age distributions, a marginally significant difference between two adjusted probability distributions should be interpreted with caution.

\section{Inbuilt Age in Other Forest Types}

Coastal western hemlock forests contain some of the largest accumulations and oldest mean age of CWD of forests worldwide (Harmon et al. 1986). Due to the dominance of shorter-lived species, faster decay rates, and/or a greater contribution of live fuels, most other forest types may have younger fuels. For example, most species in deciduous hardwood forests of the eastern United States seldom reach 350 years (Tyrrell and Crow 1994). CWD decays at a significantly faster rate in areas with warm and moist conditions for at least part of the year (e.g. tropical forests and temperate deciduous forests) than in the cool maritime forests of Vancouver Island (Harmon et al. 1986). Similarly, CWD is not persistent and young FWD comprises the majority of fuels in pine forests that experience frequent low-intensity fires (e.g. ponderosa pine of interior Pacific Northwest or slash pine of the southeastern United States) (Chandler et al. 1983). Live material comprises a large component of fuels in other vegetation types, such as resinous vegetation in Californian chaparral or Australian dry sclerophyll Eucalyptus forest. Despite these observations, investigations such as this one need to confirm a lower inbuilt age of charcoal dates in other vegetation types. This is necessary to assess the resolution of fire history studies in any given forest type.

\section{CONCLUSION}

Direct measurements of inbuilt age in coastal western hemlock forests of British Columbia suggest that the period elapsed between wood formation and combustion to charcoal may increase the ${ }^{14} \mathrm{C}$ age of charcoal beyond the age of the fire by several centuries. The inbuilt age measured in this study was mainly between 30 and 610 years (95\% confidence interval), though an upper extreme of 670 years was detected. These large inbuilt ages result from the long residence times of coarse woody debris, the consumption of the outer wood during fire, and the slow growth rates in the old trees common in this area. Inbuilt ages typically place the actual date of a fire outside of the $2 \sigma$ confidence interval of a calibrated date, therefore significantly affecting the precision of ${ }^{14} \mathrm{C}$ estimates of the dates of past fires.

The magnitude of the inbuilt age detected in this study has three main implications for using soil charcoal to reconstruct fire history in similar environments. First, inbuilt age can increase the uncertainty of a date by as much as 670 years, and thus greatly limits the ability to correlate fire events among sites. Second, to detect different fires calibrated ${ }^{14} \mathrm{C}$ ages must be at least 610 years apart (high level of certainty; 95th percentile), or 380 years apart (lower level of certainty; 75 th percentile). Therefore, ${ }^{14} \mathrm{C}$ methods do not reliably measure fire intervals within these ranges. Lastly, though soil charcoal

${ }^{14} \mathrm{C}$ ages can be useful for determining the time-since-fire, the temporal precision is coarse.

\section{ACKNOWLEDGMENTS}

I thank L B Brubaker for detailed comments and G A Meyer for reviewing the manuscript. Additional reviews by K P Lertzman, E D Ford, J K Agee, and D J Hallett were also very helpful. T A Brown (CAMS-LLNL) aided with ${ }^{14} \mathrm{C}$ measurements. This research was funded by a grant from Forest Renewal BC (HQ96235-RE) to K P Lertzman. 


\section{REFERENCES}

Agee JK, Huff MH. 1987. Fuel succession in a western hemlock/Douglas-fir forest. Canadian Journal of Forest Research 17:697-704.

Agee JK. 1993. Fire ecology of Pacific Northwest forests. Washington, D.C.: Island Press.

Aitken MJ. 1990. Science-based dating in archaeology. London: Longman Group UK Limited.

Carcaillet C. 1998. A spatially precise study of Holocene fire history, climate and human impact within the Maurienne valley, North French Alps. Journal of Ecology 86:384-96.

Chandler C, Cheney P, Thomas P, Trabaud L, Williams D. 1983. Fire in forestry, Volume I: forest fire behavior and effects. New York: John Wiley \& Sons.

Clark JS, Lynch J, Stocks BJ, Goldammer JG. 1998. Relationships between charcoal particles in air and sediments in west-central Siberia. Holocene 8:19-29.

Daniels LD, Marshall PL, Klinka K. 1995. Age structure of Thuja plicata in the tree layer of old-growth stands near Vancouver, British Columbia. Northwest Science 69:175-83.

Daniels LD, Dobry J, Klinka K, Feller MC. 1997. Determining the year of death of logs and snags of Thuja plicata in southwestern coastal British Columbia. $\mathrm{Ca}$ nadian Journal of Forest Research 27:1132-41.

DeBell DS, Franklin F. 1987. Old-growth Douglas-fir and western hemlock: a 36-year record of growth and mortality. Western Journal of Applied Forestry 2:111-4.

Fahnestock GR, Agee JK. 1983. Biomass consumption and smoke production by prehistoric and modern forest fires in western Washington. Journal of Forestry 81:653-7.

Gavin DG. 2000. Holocene fire history of a coastal temperate rain forest, Vancouver Island, British Columbia. $\mathrm{PhD}$ dissertation, University of Washington, Seattle.

Gholz HL, Grier CC, Campbell AG, Brown AT. 1979. Equations for estimating biomass and leaf area of plants in the Pacific Northwest. Research Paper 41. Oregon State University Forest Research Lab.

Graham RL, Cromack K Jr. 1982. Mass, nutrient content and decay rate of dead boles in rain forests of Olympic National Park. Canadian Journal of Forest Research 12:511-21.

Harmon ME, Franklin JF, Swanson FJ, Sollins P, Gregory SV, Lattin JD, Anderson NH, Cline SP, Aumen NG, Sedell JR, Lienkaemper GW, Cromack K Jr, Cummins KW. 1986. Ecology of coarse woody debris in temperate ecosystems. Advances in Ecological Research 15:133-302.

Hennon PE, Loopstra EM. 1991. Persistence of western hemlock and western redcedar trees 38 years after girdling at Cat Island in Southeast Alaska. Research Note $P N W-R N-507$, USDA Forest Service, Pacific NW Research Station.

Hoadley RB. 1990. Identifying wood: accurate results with simple tools. Newtown, CT: Taunton Press.
Hopkins MS, Ash J, Graham AW, Head J, Hewett RK. 1993. Charcoal evidence of the spatial extent of the Eucalyptus woodland expansions and rainforest contractions in North Queensland during the late Pleistocene. Journal of Biogeography 20:357-72.

Horn SP, Sanford RL. 1992. Holocene fires in CostaRica. Biotropica 24:354-61.

Huff MH, Agee JK. 1980. Characteristics of large lightning fires in the Olympic Mountains, Washington. Proceedings of the 6th Meteorology Conference, 22-24 April 1980, Seattle, American Meteorological Society.

Ishii H, Clement JP, Shaw DC. 2000. Branch growth and crown form in old coastal Douglas-fir. Forest Ecology and Management 131:81-91.

Lowe DJ, McFadgen BG, Higham TFG, Hogg AG, Froggatt PC, Nairn IA. 1998. Radiocarbon age of the Kaharoa tephra, a key marker for late Holocene stratigraphy and archaeology in New Zealand. The Holocene 8:499-507.

McFadgen BG. 1982. Dating New Zealand archaeology by radiocarbon. New Zealand Journal of Science 25: 379-92.

McFadgen BG, Knox FB, Cole TRL. 1994. Radiocarbon calibration curve variations and their implications for the interpretation of New Zealand prehistory. Radiocarbon 36(2):221-36.

Meidinger D, Pojar J. 1991. Ecosystems of British Columbia. British Columbia Ministry of Forests.

Meyer GA, Wells SG, Balling RC Jr, Jull AJT. 1992. Response of alluvial systems to fire and climate change in Yellowstone National Park. Nature 357:147-50.

Meyer GA, Wells SG, Jull AJT. 1995. Fire and alluvial chronology in Yellowstone National Park: climatic and intrinsic controls on Holocene geomorphic processes. Geological Society of America Bulletin 107: 1211-30

Molloy BPJ, Burrows CJ, Cox JE, Johnston JA, Wardle P. 1963. Distribution of subfossil forest remains, eastern South Island, New Zealand. New Zealand Journal of Botany 1:68-77.

Ottmar RD, Burns MF, Hall JN, Hanson AD. 1993. CONSUME users guide. USDA Forest Service General Technical Report PNW-GTR-304.

Pearson AF. 2000. Natural disturbance patterns in a coastal temperate rain forest watershed, Clayoquot Sound, British Columbia. PhD dissertation, University of Washington, Seattle, Washington.

Pickford SG, Fahnestock G, Ottmar R. 1980. Weather, fuel, and lightning fires in Olympic National Park. Northwest Science 54:92-105.

Sandberg DV, Ottmar RD. 1983. Slash burning and fuel consumption in the Douglas-fir subregion. Proceedings 7th Conference Fire and Forest Meteorology, Fort Collins, Colorado, American Meteorological Society.

Schmidt RL. 1970. A history of pre-settlement fires on Vancouver Island as determined from Douglas-fir 
ages. In: Smith JHG, Worrall J. Tree-ring analysis with special reference to Northwest America. Vancouver, B.C.: University of British Columbia Faculty of Forestry Bulletin No. 7:107-8.

Sollins P. 1982. Input and decay of coarse woody debris in coniferous stands in western Oregon and Washington. Canadian Journal of Forest Research 12:18-28.

Sollins P, Cline SP, Verhoeven T, Sachs D, Spycher G. 1987. Patterns of log decay in old-growth Douglas-fir forests. Canadian Journal of Forest Research 17: 1585-95.

Spies TA, Franklin JF, Thomas TB. 1988. Coarse woody debris in Douglas-fir forests of western Oregon and Washington. Ecology 69:1689-702.

Stocks BJ, Kauffman JB. 1997. Biomass consumption and behavior of wildland fire in boreal, temperate, and tropical ecosystems: parameters necessary to interpret historic fire regimes and future fire scenarios. In: Clark JS, Chachier H, Goldammer JG, Stocks B. Sediment records of biomass burning and global change. Berlin:
Springer Verlag. p 169-88.

Stone JN, MacKinnon A, Parminter JV, Lertzman KP. 1998. Coarse woody debris decomposition documented over 65 years on southern Vancouver Island. Canadian Journal of Forest Research 28:788-93.

Stuiver M, Reimer PJ. 1993. Extended ${ }^{14} \mathrm{C}$ database and revised CALIB radiocarbon calibration program. $\mathrm{Ra}$ diocarbon 35(1):215-30.

Stuiver M, Reimer PJ, Bard E, Beck JW, Burr GS, Hughen KA, Kromer B, McCormac G, Van der Plicht J, Spurk M. 1998. INTCAL98 radiocarbon age calibration, 24,000-0 cal BP. Radiocarbon 40(3):1041-83.

Turner J. 1984. Radiocarbon dating of wood and charcoal in an Australian forest ecosystem. Australian Forester 47:79-83.

Tyrell CE, Crow TR. 1994. Structural characteristics of old-growth hemlock-hardwood forests in relation to age. Ecology 75:370-86.

Waterbolk HT. 1983. Ten guidelines for the archaeological interpretation of radiocarbon dates. PACT 8:57-70. 